\title{
Fecal Biomarkers in Inflammatory Bowel Disease
}

\author{
Kang-Moon Lee \\ Department of Internal Medicine, The Catholic University of Korea St. Vincent Hospital, The Catholic University of Korea College of Medicine, \\ Suwon, Korea
}

Inflammatory bowel diseases (IBD) are idiopathic, remitting and relapsing diseases causing chronic inflammation of intestine. Initial diagnosis, assessment of disease activity, and prediction of treatment outcomes present challenges to physicians in clinical care of IBD. Therefore it is critical to accurately determine inflammatory activity of the gut. Endoscopy, the current gold standard for assessing and monitoring intestinal inflammation, is costly, invasive and at times, dangerous. Fecal biomarkers are a simple, reliable, non-invasive test that, because of their direct contact with the intestinal mucosa, may be more accurate in determining intestinal inflammation than serum biomarkers. Since calprotectin was identified as a marker for IBD, several additional fecal markers, including lactoferrin, S100A12, and M2-pyruvate kinase, have been evaluated for their ability to differentiate and monitor disease activity. Fecal biomarkers are useful in differentiating IBD from functional bowel disorders, monitoring response to treatment and predicting clinical and endoscopic relapse. Although they may not ever replace endoscopy, fecal markers could minimize unnecessary, potentially dangerous examinations and help guide IBD management in a more costeffective manner. (Intest Res 2013;11:73-78)

Key Words: Fecal biomarker; Mucosal healing; Inflammatory bowel disease

\section{서 론}

궤양성 대장염과 크론병으로 대표되는 염증성 장질환의 국내 유 병률이 꾸준히 증가하면서 ${ }^{1}$ 염증성 장질환을 진료하는 의사들의 임 상경험도 풍부해지고 있다. 그러나 염증성 장질환을 진단하고, 활동 성을 평가하며, 치료에 대한 반응이나 질병의 재발 등을 예측하여 환 자 개개인에 맞는 적절한 치료 계획을 세우는 일은 많은 경험을 가진 임상의사에게도 쉬운 일이 아니다. 이를 위해선 환자의 증상, 진찰소 견, 각종 혈액 및 영상검사와 내시경검사 등을 통해 염증 정도를 평가 하는 것이 중요하다. 그러나 현재까지 개발된 여러 임상지표(clinical indices)들은 대부분 너무 복잡하고 작성하는 데 시간이 소요되어 실 제 임상에서 사용하기 어려우며, 환자가 호소하는 증상이나 진찰 소 견에 근거를 두고 있어 장관의 염증 정도를 정확히 반영하지 못하는 단점이 있다. ${ }^{2}$ 내시경검사는 비용이 많이 들고 침습적 검사이므로 자 주 시행할 수 없는 문제가 있다. 따라서 장관의 염증을 객관적으로 측

Received January 25, 2013. Revised March 8, 2013

Accepted March 12, 2013.

Correspondence to Kang-Moon Lee, Department of Internal Medicine, The

Catholic University of Korea St. Vincent Hospital, 93 Jungbu-daero, Paldalgu, Suwon 442-723, Korea. Tel: +82-31-249-8151, Fax: +82-31-253-8898,

E-mail:drmaloman@catholic.ac.kr
정하고 활동성을 감시할 수 있는 간단하고 저렴하면서 비침습적인 검 사법의 필요성이 대두되었다.

대변 내의 여러 생물표지자(biomarker)는 장점막과 직접 접촉하므 로 장관의 염증을 보다 정확히 반영할 개연성이 있으며, 검사가 비침 습적이고 비교적 저렴하여 주목받고 있다. ${ }^{3}$ 최근 염증성 장질환의 감 별 진단 및 활동성의 평가 등에 있어 대변 생물표지자의 유용성에 대 한 연구가 광범위하게 진행되고 있으며 실제 임상에서도 사용되고 있 으나, 아직 국내에서는 대변 생물표지자 검사가 상용화되어 있지 않 은 실정이다. 본고에서는 대표적인 네 가지 대변 생물표지자들의 특 성을 소개하고, 염증성 장질환에서 이들의 유용성에 대해 살펴보도록 한다.

\section{대변 생물표지자}

\section{Calprotectin}

Calprotectin은 항균작용을 나타내는 36 킬로달톤의 칼슘 및 아연결합 단백질로서, 중성구의 세포질 단백의 50-60\%를 차지하며 세포 가 파괴되거나 활성화되면 세포 외로 분비되므로 염증의 정도와 잘 비례하는 민감한 표지자로 알려져 있다. ${ }^{4.5}$ Calprotectin은 세균에 의

- Copyright 2013. Korean Association for the Study of Intestinal Diseases. All rights reserved.

This is an Open Access article distributed under the terms of the Creative Commons Attribution Non-Commercial License (http://creativecommons.org/licenses/by-nc/3.0)

which permits unrestricted non-commercial use, distribution, and reproduction in any medium, provided the original work is properly cited. 
해 잘 분해되지 않아 실온에서 약 1 주일 정도 안정적으로 유지되며, 대변 내에 균일하게 분포하므로 $5 \mathrm{~g}$ 이하의 적은 양으로도 측정이 가 능하다. ${ }^{3.6}$ 현재 표준검사법인 ELISA 측정법은 결과를 얻기까지 약 5-7일이 소요되고 숙련자가 필요하여 신속한 진단 및 치료방침 결정 에 한계가 있었는데, 최근 간단하고 신속한 검사법들이 개발되어 향 후 진료에 도입될 예정이다. ${ }^{7.8}$ 대변 calprotectin은 남녀간의 차이는 없 으나, 연령에 따른 차이를 보여 신생아에서 높다가 점차 감소하여 5 세가 되면 성인과 비슷해지는 것으로 알려져 있다. ${ }^{2}$

\section{Lactoferrin}

Lactoferrin은 아연-결합 당단백질로 중성구 2 차 과립의 주성분이 며 중성구가 활성화되면 분비되어 급성염증반응의 주요 인자로 작용 한다. ${ }^{9}$ 대변 내에서 매우 안정하여 수 차례 동결-해동 과정을 거쳐도 영향을 받지 않으며 5일간 안정적으로 유지된다. ${ }^{10}$ Calprotectin과 마 찬가지로 ELISA법으로 측정이 가능하다.

\section{S100A12}

S100A12는 칼슘-결합 단백인 S100단백군의 하나로서 calgranulin $\mathrm{C}$ 라고도 불린다. 중성구의 세포질 단백으로 세포 외로 분비되어 강 력한 염증유발 작용을 나타낸다. S100A12는 receptor for advanced glycation end product (RAGE)와 결합하여 $\mathrm{NF} \kappa \mathrm{B}$ 신호전달체계를 활성화시켜 각종 염증물질을 유리시키며, 특히 단핵구와 대식세포에 대한 강력한 화학유인물질로 알려져 있다. ${ }^{11,12}$ 류마티스 관절염이나 가와사키병 등 염증성 질환 환자의 혈청에서 S100A 12 가 증가되어 있 음이 알려졌으며, 혈청 S100A12 수치와 대변 수치는 연관성을 보인 다. 대변 내에 균일하게 분포하며 실온에서 7일간 안정적으로 유지된 다. ${ }^{13}$

\section{M2-PK}

Pyruvate kinase (PK)는 모든 세포에서 발현되며 당분해경로 (glycolytic pathway)의 열쇠효소(key enzyme)로 작용한다. 이 중 $\mathrm{M} 2-\mathrm{PK}$ 는 사합체(tetramer)와 이합체(dimer) 두 가지 형태로 존재 하는데, 활동형인 사합체 $\mathrm{M} 2-\mathrm{PK}$ 는 포도당을 젖산으로 분해하는 과 정에서 에너지를 생산하여 정상적인 조직에 에너지를 공급하는 기능 을 한다. 반면 비활동형인 이합체 $\mathrm{M} 2-\mathrm{PK}$ 는 주로 종양 조직 내에 존 재하여 'tumor M2-PK'로 불리는데, 효소활성도가 낮아 당분해경 로의 중간산물인 핵산, 인지질, 아미노산 등이 축적되어 이들이 활발 한 세포 증식에 관여하는 것으로 알려져 있다. ${ }^{14,15} \mathrm{M} 2-\mathrm{PK}$ 는 혈청 및 대변에서 쉽게 측정이 가능하며, 실온에서 이틀간 안정적으로 유지 된다. ${ }^{16}$ 대장암 환자에서 대변 $\mathrm{M} 2-\mathrm{PK}$ 증가가 보고되어 대장암 선별 검사로서의 유용성에 대한 연구가 진행되고 있으며, ${ }^{17}$ 최근 장 염증의 표지자로서 주목받고 있다. ${ }^{15}$
염증성 장질환에서 대변 생물표지자의 유용성

\section{1. 진단}

\section{1) 염증성 장질환과 과민성 장증후군의 감별}

복통이나 설사 등의 증상을 호소하는 환자에서 그 원인이 기질적 인지 기능성인지 감별하는 것이 중요하다. 염증성 장질환의 경우에는 체중감소, 빈혈, 혈변 등 기질적 원인을 시사하는 증상이나 증후가 동 반되는 경우가 흔하지만, 때론 과민성 장증후군과의 감별이 어려운 경우가 있으며, 감별을 위해 내시경검사가 필요하게 된다. 만일 염증 성 장질환에 특이적인 생물표지자가 있다면 과민성 장증후군 환자에 서 불필요한 내시경검사를 피할 수 있으므로, 특히 서구처럼 내시경검 사 비용이 고가인 지역에선 유용할 것이다.

염증성 장질환을 가진 성인 및 소아에서 대변 calprotectin 수치는 정상대조군에 비해 증가되어 있으며, 과민성 장증후군 환자와 정상대 조군 간에는 차이가 없다고 보고되었다. ${ }^{4,18,19}$

장 증상을 호소하는 환자의 염증성 장질환 감별에서 대변 calprotectin의 역할에 대한 체계적 고찰에서 대변 calprotectin 검사는 높은 음성예측도를 나타냈으나 양성예측도는 상대적으로 낮았다. ${ }^{4}$ 염증성 장질환 감별을 위한 이상적인 절사값(cut-off value)은 아직 정해져 있지 않으나, 한 메타분석에서 절사값을 $50 \mu \mathrm{g} / \mathrm{g}$ 으로 했을 때 민감도 와 특이도는 $89 \%, 81 \%$ 였으며, 절사값을 $100 \mu \mathrm{g} / \mathrm{g}$ 으로 했을 때는 각 각 $98 \%, 91 \%$ 였다. ${ }^{18}$ 또 다른 메타분석에서 대변 calprotectin의 민감 도와 특이도는 $93 \%, 96 \%$ 였으며, 염증성 장질환이 의심되는 환자에 서 선별검사로 사용할 경우 내시경검사가 필요한 환자의 수를 $67 \%$ 감소시키는 효과를 나타냈다. ${ }^{19}$ 반면에 검사결과가 위음성을 보임으 로 인해 약 $6 \%$ 의 환자에서 진단이 늦어지는 문제가 있었다.

19 개의 연구, 1,001 명의 환자를 분석한 결과, 염증성 장질환 진단 에 있어 대변 lactoferrin의 평균 민감도는 $80 \%$, 특이도는 $82 \%$ 였으 며, ${ }^{20}$ 일부 연구에서는 $100 \%$ 의 특이도를 보여 대변 lactoferrin이 증가 된 경우 과민성 장증후군을 완전히 배제할 수 있었다. ${ }^{21}$ 대변 lactoferrin, calprotectin, polymorphonuclear neutrophil (PMN)-elastase와 $\mathrm{CRP}$ 등 네 가지 생물표지자를 비교한 결과, calprotectin과 lactoferrin의 염증성 장질환 진단정확도는 동일하게 $80 \%$ 로, PMN-elastase (74.1\%)나 CRP (64\%)보다 높았다. ${ }^{22}$ 크론병에서는 calprotectin (84\%)이 가장 높은 진단 정확도를 보인 반면, 궤양성 대장염에서는 lactoferrin (83.3\%)이 가장 높았다. 이 연구의 저자들은 네 가지 생 물표지자와 임상지표를 종합한 comprehensive index를 제시하였는 데, 이를 이용하면 궤양성 대장염의 진단 정확도를 $95.3 \%$ 까지 높일 수 있었다.

소아 염증성 장질환 환자를 대상으로 한 연구에서 대변 S100A12 의 절사값을 $10 \mathrm{mg} / \mathrm{kg}$ 으로 했을 때 민감도 $96 \%$, 특이도 $92 \%$ 로 환 자군과 정상대조군을 감별할 수 있었다. ${ }^{13}$ 같은 기관에서 S100A12를 calprotectin과 비교한 연구에서는 소아 염증성 장질환군이 정상대조 군에 비해 대변 S100A12가 증가되어 있었으며 $(55.2 \mathrm{mg} / \mathrm{kg}$ VS. 1.1 $\mathrm{mg} / \mathrm{kg}, P<0.00001)$, 염증성 장질환 진단의 민감도와 특이도는 모 두 $97 \%$ 로 calprotectin (각각 $100 \%, 67 \%$ )과 유사하였다. ${ }^{23}$ 성인 염증 
성 장질환 환자에서도 대변 $\mathrm{S} 100 \mathrm{~A} 12$ 는 과민성 장증후군 및 정상대 조군과의 감별에 있어 높은 민감도와 특이도를 나타냈다. ${ }^{24}$

$\mathrm{M} 2-\mathrm{PK}$ 의 유용성에 대한 연구는 가장 최근에 이루어졌다. 50명 의 궤양성 대장염, 31 명의 크론병, 43 명의 과민성 장증후군, 7 명의 대 장암 환자를 대상으로 대변 M2-PK와 calprotectin을 측정한 결과, 궤양성 대장염, 크론병 및 대장암 환자에서 과민성 장증후군 환자에 비해 M2-PK가 유의하게 증가되어 있었고, 이는 calprotectin 수치 와 강한 연관성을 나타냈다. ${ }^{15}$ 대변 $\mathrm{M} 2-\mathrm{PK}$ 의 절사값을 $3.7 \mathrm{U} / \mathrm{mL}$ 로 했을 때 기질적 질환 진단의 민감도, 특이도, 양성 예측치는 각각 $73 \%, 74 \%, 89 \%$ 였다. 소아 염증성 장질환 환자에서도 건강대조군에 비해 대변 M2-PK 수치가 높았고, 특히 활동성 질환인 경우 $90 \%$ 이 상의 환자에서 $\mathrm{M} 2-\mathrm{PK}$ 수치가 증가되었다. ${ }^{25}$

\section{2) 소장 크론병의 진단}

내시경으로 관찰이 어려운 소장의 염증 여부를 정확히 반영하고 진 단할 수 있는 생물표지자가 있다면 임상에서 매우 유용할 것이다. 소 장 병변 진단의 대변 calprotectin 유용성을 조사한 연구에서, 소장조 영술을 통해 소장 병변이 진단된 모든 증례에서 대변 calprotectin 수 치가 $60 \mu \mathrm{g} / \mathrm{g}$ 보다 높았다. 즉, 대변 calprotectin 수치가 $60 \mu \mathrm{g} / \mathrm{g}$ 보 다 낮을 경우 음성예측치는 $100 \%$ 였다. 이를 근거로 저자들은 대변 calprotectin 수치가 $60 \mu \mathrm{g} / \mathrm{g}$ 미만일 경우, 소장조영술을 시행할 필요 가 없다고 주장하였다. ${ }^{26}$ 그러나 캡슐내시경을 이용한 최근의 연구에 서는 대변 calprotectin과 S100A12 모두 낮은 민감도로 인해 소장 크 론병의 선별검사로서의 유용성은 낮다고 하였다. ${ }^{27}$ 이 연구에서 캡슐 내시경을 통해 소장 크론병으로 진단된 환자에서 정상군이나 다른 질 환(NSAID 장염, 용종 등)이 진단된 군에 비해 calprotectin이 유의하 게 높았으나 S100A12는 각 군 간에 차이를 보이지 않았으며, 검사의 민감도와 특이도는 각각 calprotectin이 59\%, $71 \%$ 였고 S100A12는 $59 \%, 66 \%$ 였다.

\section{3) 대변 생물표지자가 증가하는 다른 질환들}

대변 생물표지자가 과민성 장증후군으로부터 염증성 장질환을 감 별하는 데 유용한 검사이지만 염증성 장질환에만 특이적인 검사는 아 니다. 세균성 혹은 바이러스성 장염, 위장관의 악성종양 및 폴립, 복 강병(celiac disease), 현미경장염, 혹은 NSAID 복용 시에도 대변 내 생물표지자가 증가할 수 있으므로 ${ }^{19,20}$ 검사 결과를 판독할 때 유의해 야 한다.

\section{2. 활성도 평가}

염증성 장질환의 활동성을 평가하는 임상적, 내시경적 및 조직학 적 지표들과 대변 생물표지자와 연관성에 대한 연구들이 진행되었다. 79 명의 염증성 장질환 환자를 12 개월 간 추적 관찰한 연구에서 대 변 calprotectin은 궤양성 대장염에서 임상지표와 비례하여 질병활성 도를 잘 반영했으나, 크론병에서는 유의한 결과를 보이지 못했다. ${ }^{28}$ 164 명의 크론병 환자를 대상으로 한 연구에서도 대변 calprotectin 및 lactoferrin 모두 임상지표인 CDAI와 유의한 상관 관계를 보이지 않
았던 반면, 내시경적 활성도와는 상관 관계를 보였다. ${ }^{29}$ 그러나 CDAI 와 유의한 상관 관계를 보였다는 보고도 있다. ${ }^{30}$ 같은 연구에서 대변 calprotectin과 lactoferrin 모두 내시경적 활성도 지표와도 상관 관계 를 보였으며, 조직검사에서 염증소견을 보였던 52 명의 환자 중 49 명 에서 대변 lactoferrin 양성, 40 명에서 calprotectin 양성을 보여 조직 학적 활성도와도 연관을 보였다. 연구들을 종합하면, 염증성 장질환 에서 내시경 점수와 대변 calprotectin의 상관계수는 0.48-0.83이며, lactoferrin의 경우엔 0.19-0.87로 보고되었다. ${ }^{31}$ 소아를 대상으로 한 연구에서 대변 calprotectin 농도는 내시경 소견보다도 조직학적 염증 정도와 더 밀접한 상관 관계를 나타냈고, ${ }^{32}$ 점막의 염증 정도와도 강 한 연관성을 보여 ${ }^{33}$ 향후 임상적 및 내시경적 관해를 넘어 조직학적 관해를 목표로 하는 치료 패러다임의 변화에 있어 대변 생물표지자가 중요한 역할을 할 것으로 기대된다.

$\mathrm{S} 100 \mathrm{~A} 12$ 는 염증성 장질환에서 내시경 및 조직학적인 염증 정도를 반영함에 있어 calprotectin보다 더 우수한 결과를 보였다. ${ }^{24}$ 또 calprotectin은 세균성 장염과 바이러스성 장염 모두에서 증가한 반면에 $\mathrm{S} 100 \mathrm{~A} 12$ 는 바이러스성 장염에서는 증가되지 않아, 저자들은 일단 세 균성 장염만 감별이 된다면 대변 S100A12가 calprotectin보다 우수한 표지자라고 하였다.

대변 M2-PK 역시 크론병과 궤양성 대장염 모두에서 활동성인 경 우 비활동성인 경우에 비해 유의하게 높아 질병 활성도를 반영하였 다. ${ }^{15}$ 그러나 소아 환자를 대상으로 한 연구에서는 관해 상태의 궤양 성 대장염 환자에서 활동기 환자에 비해 $\mathrm{M} 2-\mathrm{PK}$ 값이 유의하게 낮 았으나 크론병에서는 두 군 간에 차이가 없었다. ${ }^{25}$ 이처럼 여러 대변 생물표지자와 크론병의 활성도가 상관관계를 보이지 않는 이유 중 하나는 크론병 활성도 평가에 이용되는 임상지표가 실제 질병 활성도 를 정확히 반영하지 못하기 때문으로 생각된다.

\section{3. 치료에 대한 반응 평가}

염증성 장질환에서 치료에 대한 반응을 평가하고 예측하는 데 있 어 대변 생물표지자들이 이용되고 있다. 38명의 염증성 장질환 환자 를 대상으로 치료 전후 대변 calprotectin을 측정한 결과, 궤양성 대장 염 환자에서 치료 8 주째 완전반응을 보인 경우 유의한 감소를 보였 으나 $(P<0.01)$ 부분반응 혹은 무반응을 보인 경우엔 유의한 변화가 없었다. 크론병 환자에서도 완전반응을 보인 경우 대변 calprotectin 이 감소하는 경향을 보였다 $(P=0.13) .8$ 주째 대변 calprotectin이 정상 화된 환자들은 $100 \%$ 완전반응을 보였던 반면, 계속 증가되어 있었던 경우엔 $30 \%$ 의 환자가 불완전반응을 보여, 치료 후 대변 calprotectin 의 정상화가 성공적인 치료결과를 예측하는 대리표지자로서의 가능 성을 보였다. ${ }^{34}$ 급성 중증 궤양성 대장염 환자에서 대장절제술이 필 요했던 경우에 그렇지 않은 경우에 비해 대변 calprotectin이 유의하 게 높았으며 Kaplan-Meier 분석에서 $1,922.5 \mu \mathrm{g} / \mathrm{g}$ 을 절사값으로 했 을 때 1.1 년의 추적기간 동안 $87 \%$ 의 환자에서 대장절제술이 필요하 여, 대변 calprotectin이 대장절제술의 예측인자였다. ${ }^{35}$ 급성 중증 소아 궤양성 대장염에서 calprotectin, lactoferrin, M2-PK, S100A12 등 네 가지 대변 표지자를 비교한 연구에서 $\mathrm{M} 2-\mathrm{PK}$ 가 다른 표지자들에 
비해 스테로이드 치료에 대한 반응을 예측하는 데 가장 우수하였고, calprotectin도 어느 정도 예측도를 보였지만 lactoferrin과 S100A12 는 치료반응을 예측하지 못했다. ${ }^{36}$ 하지만 M2-PK조차도 단순히 문 진만으로 반응을 평가하는 pediatric UC activity index보다 예측도가 낮은 것으로 나타나 향후 유용성에 대한 추가적인 연구가 필요할 것 으로 생각된다.

염증성 장질환 치료의 목표인 점막치유를 확인하기 위해선 침습 적이고 비교적 고가인 내시경검사가 필수적인데, 이를 대신할 점막치 유의 대리표지자로서 대변 생물표지자가 주목받고 있다. 내과적 치 료 후 점막치유가 유도된 경우 궤양성 대장염과 크론병 모두에서 대 변 calprotectin이 $50 \mu \mathrm{g} / \mathrm{g}$ 이하로 감소되었고, ${ }^{37}$ 궤양성 대장염 치료 후 대변 lactoferrin이 Mayo score 감소와 비례하여 유의하게 감소한 다고 보고되었다. ${ }^{38}$ 특히 기존의 치료에 비해 점막치유 효과가 우수한 것으로 알려진 생물학제제 치료 후 반응을 관찰하고 예측하는 데 대 변 생물표지자가 유용한 것으로 보고되고 있다. 15 명의 크론병 환자 를 대상으로 한 초기 연구에서 항 tumor necrosis factor (TNF) 치료 후 대변 calprotectin과 lactoferrin 모두 유의한 감소를 보였으며, 이는 Crohn's disease endoscopic index of severity (CDEIS)와 밀접한 연 관을 보여 두 표지자 모두 점막치유를 잘 반영하였다. ${ }^{39} 53$ 명의 궤양 성 대장염 환자에서 infliximab 유도요법( $0,2,6$ 주)을 하면서 매주 대변 calprotectin을 측정하여 변화를 관찰한 결과, 10 주째 calprotectin의 중간값은 $1,260 \mu \mathrm{g} / \mathrm{g}$ 에서 $72.5 \mu \mathrm{g} / \mathrm{g}$ 으로 감소하였으며, 특히 10 주째 내시경적 관해가 유도된 환자에서는 치료 2 주째 calprotectin 이 급격히 감소하였다. ${ }^{40}$ 즉 infliximab 치료 후 calprotectin이 빠르게 감소할 경우 점막치유를 예측할 수 있었다.

\section{4. 재발 예측}

\section{1) 관해 후 재발 예측}

임상적 관해 상태의 염증성 장질환 환자 80 명을 1 년 동안 추적 관 찰한 연구에서 재발군과 비재발군 간에 대변 calprotectin의 유의한 차이를 보였으며(크론병, $122 \mathrm{vS.} 41.5 \mu \mathrm{g} / \mathrm{g}$; 궤양성 대장염, $123 \mathrm{vS}$. $29.0 \mu \mathrm{g} / \mathrm{g} ; P<0.0001)$, 절사값 $50 \mu \mathrm{g} / \mathrm{g}$ 에서 민감도 $90 \%$, 특이 도 $83 \%$ 로 재발의 위험을 예측할 수 있었다. ${ }^{41}$ 그러나 동일한 디자인 의 다른 연구에서는 궤양성 대장염의 경우 재발군과 비재발군의 대 변 calprotectin 수치가 유의한 차이를 보인 반면(220.6 vs. $67 \mu \mathrm{g} / \mathrm{g}$ ), 크론병에서는 두 군 간에 차이가 없어 다른 결과를 보였다. 이 연구에 서 대변 calprotectin이 $150 \mu \mathrm{g} / \mathrm{g}$ 이상인 경우 재발의 위험도는 궤양 성 대장염은 14 배, 크론병은 2 배로, 크론병보다는 궤양성 대장염에서 재발의 강력한 예측인자였다. ${ }^{28}$ 65명의 크론병 환자를 대상으로 한 전향적 연구에서 infliximab 유도요법 후 관해가 된 환자 50명(77\%) 중 23명이 1년 내에 재발을 경험하였는데, 14 주째 대변 calprotectin 수치는 관해유지군과 재발군 간에 차이가 없어 재발을 예측하지 못 했다. ${ }^{42}$ 반면 infliximab 중단 후 재발의 예측인자를 조사한 STORI 연 구에서는 남성, 백혈구 $>6,000 / \mathrm{mm}^{3}$, 혈색소 $\leq 14.5 \mathrm{~g} / \mathrm{dL}, \mathrm{CRP} \geq$ $0.5 \mathrm{mg} / \mathrm{dL}$, 대변 calprotectin $\geq 300 \mu \mathrm{g} / \mathrm{g}$ 등이 재발의 위험인자로 나타났다. ${ }^{43}$ 항TNF 치료를 받은 60 명의 염증성 장질환 환자(크론병
34 명, 궤양성 대장염 26명)를 대상으로 한 최근 연구에서도 유도요법 후 대변 calprotectin이 정상화된 31 명 중 26명(84\%)이 1년 후에 임상 적 관해 상태였던 것에 비해 calprotectin이 $100 \mu \mathrm{g} / \mathrm{g}$ 이상으로 증가 되어 있었던 29 명 중 11 명 $(38 \%)$ 만이 관해 상태를 유지하고 있었으며, 절사값을 $129 \mu \mathrm{g} / \mathrm{g}$ 으로 했을 때 민감도 $72 \%$, 특이도 $80 \%$ 로 1년 후 활동성 질환의 위험을 예측할 수 있었다. ${ }^{4}$

\section{2) 수술 후 재발 예측}

회장-결장절제술(ileocolonic resection)을 통해 수술적 관해가 된 크론병 환자의 대변 생물표지자의 유용성에 대한 연구에서 수술 후 40.5개월의 추적기간 동안 대변 calprotectin은 평균 $247.0 \pm 22.7$ $\mathrm{ng} / \mathrm{mL}$, lactoferrin은 평균 $21.0 \pm 3.9 \mu \mathrm{g} / \mathrm{g}$ 로 수술 후에도 비교적 오랫동안 높게 유지되어 수술 후 재발을 예측하기에 대변 표지자의 유용성은 제한적일 것이라고 보고되었으나, ${ }^{45}$ 그 후 다른 전향적 연구 에서는 수술 후 별다른 합병증이 없다면 2개월 내로 calprotectin 및 lactoferrin 수치가 정상화되며, CRP나 내시경 소견보다 더 정확하게 수술 후 재발을 예측할 수 있었다. ${ }^{46}$

결 론

대변 생물표지자는 염증성 장질환의 진료에 있어 기능성 장질환과 의 감별, 질병의 활성도 평가, 치료 후 반응의 평가 및 예측, 내과적 혹은 수술적 관해 후 재발의 예측 등 다양한 방면에서 유용성이 입증 되고 있다. 대변 생물표지자가 현재 진단의 기준이 되는 내시경을 대 체할 수 있는 것은 아니지만, 이에 대한 경험과 정보가 축적된다면 불 필요한 검사를 줄이고 적절한 진료 지침을 마련하는 데 도움이 될 것 이다. 하지만 각종 장염이나 장관 종양 등 다른 질환에서도 증가할 수 있으므로 결과 판독에 주의해야 한다. 멀지 않은 장래에 국내에서도 대변 생물표지자를 임상에서 이용할 수 있게 될 것이므로 각각 표지 자들의 특성 및 임상에서의 유용성 등에 대해 숙지하여 적절히 사용 한다면 염증성 장질환 환자의 진료에 도움이 될 것으로 기대한다.

\section{REFERENCES}

1. Yang SK, Yun S, Kim JH, et al. Epidemiology of inflammatory bowel disease in the Songpa-Kangdong district, Seoul, Korea, 1986-2005: a KASID study. Inflamm Bowel Dis 2008;14:542-549.

2. Judd TA, Day AS, Lemberg DA, Turner D, Leach ST. Update of fecal markers of inflammation in inflammatory bowel disease. J Gastroenterol Hepatol 2011;26:1493-1499.

3. Desai D, Faubion WA, Sandborn WJ. Review article: biological activity markers in inflammatory bowel disease. Aliment Pharmacol Ther 2007;25:247-255.

4. Konikoff MR, Denson LA. Role of fecal calprotectin as a biomarker of intestinal inflammation in inflammatory bowel disease. Inflamm Bowel Dis 2006;12:524-534.

5. Røseth AG, Fagerhol MK, Aadland E, Schjønsby H. Assessment of the neutrophil dominating protein calprotectin in feces. A methodologic study. Scand J Gastroenterol 1992;27:793-798. 
6. Joishy M, Davies I, Ahmed M, et al. Fecal calprotectin and lactoferrin as noninvasive markers of pediatric inflammatory bowel disease. J Pediatr Gastroenterol Nutr 2009;48:48-54.

7. Kolho KL, Turner D, Veereman-Wauters G, et al. Rapid test for fecal calprotectin levels in children with Crohn disease. J Pediatr Gastroenterol Nutr 2012;55:436-439.

8. Wassell J, Wallage M, Brewer E. Evaluation of the Quantum Blue rapid test for faecal calprotectin. Ann Clin Biochem 2012;49:5558.

9. Baveye S, Elass E, Mazurier J, Spik G, Legrand D. Lactoferrin: a multifunctional glycoprotein involved in the modulation of the inflammatory process. Clin Chem Lab Med 1999;37:281-286.

10. Sugi K, Saitoh O, Hirata I, Katsu K. Fecal lactoferrin as a marker for disease activity in inflammatory bowel disease: comparison with other neutrophil-derived proteins. Am J Gastroenterol 1996;91:927-934.

11. Hofmann MA, Drury S, Fu C, et al. RAGE mediates a novel proinflammatory axis: a central cell surface receptor for S100/ calgranulin polypeptides. Cell 1999;97:889-901.

12. Yang Z, Tao T, Raftery MJ, Youssef P, Di Girolamo N, Geczy CL. Proinflammatory properties of the human S100 protein S100A12. J Leukoc Biol 2001;69:986-994.

13. de Jong NS, Leach ST, Day AS. Fecal S100A12: a novel noninvasive marker in children with Crohn's disease. Inflamm Bowel Dis 2006;12:566-572.

14. Mazurek S. Pyruvate kinase type M2: a key regulator of the metabolic budget system in tumor cells. Int J Biochem Cell Biol 2011;43:969-980.

15. Chung-Faye G, Hayee B, Maestranzi S, Donaldson N, Forgacs I, Sherwood R. Fecal M2-pyruvate kinase (M2-PK): a novel marker of intestinal inflammation. Inflamm Bowel Dis 2007;13:13741378.

16. Haug U, Wente MN, Seiler CM, Rothenbacher D, Büchler MW, Brenner H. Tumor M2 pyruvate kinase as a stool marker for colorectal cancer: stability at room temperature and implications for application in the screening setting. Clin Chem 2006;52:782-784.

17. Tonus C, Sellinger M, Koss K, Neupert G. Faecal pyruvate kinase isoenzyme type M2 for colorectal cancer screening: a metaanalysis. World J Gastroenterol 2012;18:4004-4011.

18. von Roon AC, Karamountzos L, Purkayastha S, et al. Diagnostic precision of fecal calprotectin for inflammatory bowel disease and colorectal malignancy. Am J Gastroenterol 2007;102:803813.

19. van Rheenen PF, Van de Vijver E, Fidler V. Faecal calprotectin for screening of patients with suspected inflammatory bowel disease: diagnostic meta-analysis. BMJ 2010;341:c3369.

20. Gisbert JP, McNicholl AG, Gomollon F. Questions and answers on the role of fecal lactoferrin as a biological marker in inflammatory bowel disease. Inflamm Bowel Dis 2009;15:1746-1754.

21. Kane SV, Sandborn WJ, Rufo PA, et al. Fecal lactoferrin is a sensitive and specific marker in identifying intestinal inflammation. Am J Gastroenterol 2003;98:1309-1314.

22. Langhorst J, Elsenbruch S, Koelzer J, Rueffer A, Michalsen A,
Dobos GJ. Noninvasive markers in the assessment of intestinal inflammation in inflammatory bowel diseases: performance of fecal lactoferrin, calprotectin, and PMN-elastase, CRP, and clinical indices. Am J Gastroenterol 2008;103:162-169.

23. Sidler MA, Leach ST, Day AS. Fecal S100A12 and fecal calprotectin as noninvasive markers for inflammatory bowel disease in children. Inflamm Bowel Dis 2008;14:359-366.

24. Kaiser T, Langhorst J, Wittkowski H, et al. Faecal S100A12 as a non-invasive marker distinguishing inflammatory bowel disease from irritable bowel syndrome. Gut 2007;56:1706-1713.

25. Czub E, Herzig KH, Szaflarska-Popawska A, et al. Fecal pyruvate kinase: a potential new marker for intestinal inflammation in children with inflammatory bowel disease. Scand J Gastroenterol 2007;42:1147-1150.

26. Dolwani S, Metzner M, Wassell JJ, Yong A, Hawthorne AB. Diagnostic accuracy of faecal calprotectin estimation in prediction of abnormal small bowel radiology. Aliment Pharmacol Ther 2004;20:615-621.

27. Sipponen T, Haapamäki J, Savilahti E, et al. Fecal calprotectin and S100A12 have low utility in prediction of small bowel Crohn's disease detected by wireless capsule endoscopy. Scand J Gastroenterol 2012;47:778-784.

28. Costa F, Mumolo MG, Ceccarelli L, et al. Calprotectin is a stronger predictive marker of relapse in ulcerative colitis than in Crohn's disease. Gut 2005;54:364-368.

29. Jones J, Loftus EV Jr, Panaccione R, et al. Relationships between disease activity and serum and fecal biomarkers in patients with Crohn's disease. Clin Gastroenterol Hepatol 2008;6:1218-1224.

30. Vieira A, Fang CB, Rolim EG, et al. Inflammatory bowel disease activity assessed by fecal calprotectin and lactoferrin: correlation with laboratory parameters, clinical, endoscopic and histological indexes. BMC Res Notes 2009;2:221.

31. Lewis JD. The utility of biomarkers in the diagnosis and therapy of inflammatory bowel disease. Gastroenterology 2011;140:1817-1826.

32. Bunn SK, Bisset WM, Main MJ, Golden BE. Fecal calprotectin as a measure of disease activity in childhood inflammatory bowel disease. J Pediatr Gastroenterol Nutr 2001;32:171-177.

33. Canani RB, Terrin G, Rapacciuolo L, et al. Faecal calprotectin as reliable non-invasive marker to assess the severity of mucosal inflammation in children with inflammatory bowel disease. Dig Liver Dis 2008;40:547-553.

34. Wagner M, Peterson CG, Ridefelt P, Sangfelt P, Carlson M. Fecal markers of inflammation used as surrogate markers for treatment outcome in relapsing inflammatory bowel disease. World J Gastroenterol 2008;14:5584-5589.

35. Ho GT, Lee HM, Brydon G, et al. Fecal calprotectin predicts the clinical course of acute severe ulcerative colitis. Am J Gastroenterol 2009;104:673-678.

36. Turner D, Leach ST, Mack D, et al. Faecal calprotectin, lactoferrin, M2-pyruvate kinase and S100A12 in severe ulcerative colitis: a prospective multicentre comparison of predicting outcomes and monitoring response. Gut 2010;59:1207-1212.

37. Røseth AG, Aadland E, Grzyb K. Normalization of faecal calpro- 
tectin: a predictor of mucosal healing in patients with inflammatory bowel disease. Scand J Gastroenterol 2004;39:1017-1020.

38. Masoodi I, Kochhar R, Dutta U, et al. Fecal lactoferrin, myeloperoxidase and serum C-reactive are effective biomarkers in the assessment of disease activity and severity in patients with idiopathic ulcerative colitis. J Gastroenterol Hepatol 2009;24:17681774

39. Sipponen T, Savilahti E, Kärkkäinen P, et al. Fecal calprotectin, lactoferrin, and endoscopic disease activity in monitoring antiTNF-alpha therapy for Crohn's disease. Inflamm Bowel Dis 2008;14:1392-1398.

40. De Vos M, Dewit O, D'Haens G, et al; behalf of BIRD. Fast and sharp decrease in calprotectin predicts remission by infliximab in anti-TNF naïve patients with ulcerative colitis. J Crohns Colitis 2012;6:557-562.

41. Tibble JA, Sigthorsson G, Bridger S, Fagerhol MK, Bjarnason I. Surrogate markers of intestinal inflammation are predictive of relapse in patients with inflammatory bowel disease. Gastroenterology 2000;119:15-22.
42. Laharie D, Mesli S, El Hajbi F, et al. Prediction of Crohn's disease relapse with faecal calprotectin in infliximab responders: a prospective study. Aliment Pharmacol Ther 2011;34:462-469.

43. Louis E, Mary JY, Vernier-Massouille G, et al; Groupe D'etudes Thérapeutiques Des Affections Inflammatoires Digestives. Maintenance of remission among patients with Crohn's disease on antimetabolite therapy after infliximab therapy is stopped. Gastroenterology 2012;142:63-70.

44. Molander P, af Björkesten CG, Mustonen H, et al. Fecal calprotectin concentration predicts outcome in inflammatory bowel disease after induction therapy with $\mathrm{TNF} \alpha$ blocking agents. Inflamm Bowel Dis 2012;18:2011-2017.

45. Scarpa M, D'Incà R, Basso D, et al. Fecal lactoferrin and calprotectin after ileocolonic resection for Crohn's disease. Dis Colon Rectum 2007;50:861-869.

46. Lamb CA, Mohiuddin MK, Gicquel J, et al. Faecal calprotectin or lactoferrin can identify postoperative recurrence in Crohn's disease. Br J Surg 2009;96:663-674. 